\title{
Perbedaan Respon Hematologi dan Perkem- bangan Kognitif pada Anak Anemia Defisiensi Besi Usia Sekolah Dasar yang Mendapat Terapi Besi Satu Kali dan Tiga kali Sehari
}

\author{
Bidasari Lubis, Rina AC Saragih, Dedi Gunadi, Nelly Rosdiana, Elvi Andriani* \\ Departemen Ilmu Kesehatan Anak Fakultas Kedokteran Universitas Sumatera Utara / RS H Adam Malik, \\ Medan, ${ }^{*}$ Fakultas Psikologi Universitas Sumatera Utara
}

\begin{abstract}
Latar belakang. Anemia defisiensi besi (ADB) dapat menyebabkan gangguan belajar dan mental dalam jangka panjang, bahkan dapat menetap. Tingkat kepatuhan pengobatan yang diberikan tiga kali sehari masih rendah. Hal ini dapat ditingkatkan dengan pemberian satu kali sehari sehingga diharapkan pengobatan akan berhasil.

Tujuan. Membandingkan respon pengobatan pada pemberian sulfas frosus satu kali sehari dengan 3 kali sehari pada anak usia sekolah yang menderita anemia defisiensi besi.

Metode. Penelitian dilakukan di Kecamatan Bilah Hulu, Kabupaten Rantau Prapat terhadap murid sekolah dasar. Anak dengan $\mathrm{Hb}<12$, hipokrom mikrositer, Mentzer Index $>13$ dan RDW index $>220$ diikutsertakan dalam penelitian. Fungsi kognitif dinilai dengan Weschler Intelligence Scale for Children. Sampel secara random dibagi menjadi 2 kelompok yang mendapat sulfas ferosus 3 kali sehari dan satu kali sehari dengan dosis yang sama (besi elemental $5 \mathrm{mg} / \mathrm{kgBB} / \mathrm{hari}$ ).

Hasil. Lima puluh anak dinilai dengan WISC, didapati rerata Full IQ 83,80 (SD=13,14), Performance IQ 81,08 (SD=14,58) dan Verbal IQ 88,10 ( $S D=14,20)$. Didapatkan skor aritmatika yang rendah $(7 \pm 3,23)$. Tingkat IQ didapati average $36 \%$, dull normal $28 \%$, borderline $24 \%$, dan mental defective $10 \%$. Konsentrasi yang rendah dijumpai pada $44 \%$ dan sangat rendah $10 \%$. Terdapat peningkatan bermakna kadar hemoglobin pada kedua kelompok setelah pemberian terapi besi $(p<0,05)$, namun tidak dijumpai perbedaan bermakna peningkatan $\mathrm{Hb}$ antar kedua kelompok $(p=0,29)$.

Kesimpulan. Full IQ anak sekolah dasar yang menderita anemia defisiensi besi tidak melebihi tingkat average, didapati gangguan konsentrasi dan fungsi kognitif, terutama dalam matematika. Tidak didapati perbedaan bermakna antara kelompok terapi besi tiga kali sehari dibandingkan satu kali sehari dalam peningkatan Hb. (Sari Pediatri 2008;10(3):184-9).
\end{abstract}

Kata kunci: anemia defisiensi besi, sulfas ferosus, kognitif

\begin{abstract}
Alamat Korespondensi:
Prof. dr. Bidasari Lubis, SpA(K). Departemen Ilmu Kesehatan Anak Fakultas Kedokteran Sumatera Utara / RSUP H. Adam Malik Medan Jl. Bunga Lau No. 17 Medan. Tel. (061) 8361721-8365663. Fax (061) 8361721 E-mail: bikafkusu@telkom.net; kotak pos 697 Medan 20136
\end{abstract}

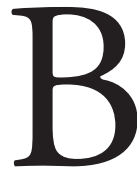
esi adalah bahan esensial yang merupakan komponen hemoglobin untuk transport oksigen ke jaringan dan sebagai komponen dari sitokrom yang sangat penting dalam 
mekanisme oksidatif pada seluruh sel hidup. ${ }^{1}$ Anemia defisiensi besi adalah anemia yang disebabkan oleh kurangnya besi yang diperlukan untuk sintesis hemoglobin. ${ }^{2}$ Anemia defisiensi besi terjadi bila asupan besi ke eritroid di sumsum tulang sangat terganggu menyebabkan konsentrasi hemoglobin menurun. Keadaan ini menyebabkan mikrositosis dan hipokromia yang progresif. ${ }^{3}$ Anemia defisiensi besi lebih sering ditemukan di negara sedang berkembang sehubungan dengan kemampuan ekonomi yang terbatas, masukan protein hewani yang rendah dan infestasi parasit seperti infeksi cacing tambang atau schitosomiasis. ${ }^{4}$

Angka kejadian anemia defisiensi besi pada anak usia sekolah (5-8 tahun) di kota sekitar 5,5\% ${ }^{2}$ Di Indonesia anemia didapati pada $40,5 \%$ balita, $47,2 \%$ usia sekolah, 57,1\% remaja putri, dan 50,9\% ibu hamil. ${ }^{5}$ Penelitian pada 1000 anak sekolah yang dilakukan oleh IDAI di 11 propinsi menunjukkan prevalensi anemia 20\%-25\%. Jumlah anak yang mengalami defisiensi besi tanpa anemia jauh lebih banyak lagi. ${ }^{6}$ Di negara maju seperti Amerika Serikat prevalensi defisiensi besi pada anak umur 1-2 tahun mencapai $9 \%$, dimana 3\% diantaranya menderita anemia. ${ }^{7}$

Defisiensi besi dapat memberikan dampak negatif pada pertumbuhan dan perkembangan anak. Defisiensi besi selain dapat mengakibatkan komplikasi ringan yang dapat sembuh dengan pemberian besi, dapat pula memberikan komplikasi yang berat misalnya striktur esofagus, penurunan daya tahan tubuh terhadap infeksi, gangguan prestasi belajar atau gangguan mental lain yang dapat berlangsung lama bahkan menetap. Oleh karena itu pengobatan terhadap defisiensi besi harus dimulai sedini mungkin, demikian pula dengan tindakan pencegahannya. ${ }^{3,8}$ Fungsi kognitif merupakan fungsi untuk mengambil, menyimpan dan menyajikan kembali berbagai bentuk ingatan. Perubahan kognitif dan tingkah laku merupakan gejala yang paling penting dari defisiensi besi pada bayi. ${ }^{9}$

Hubungan antara defisiensi besi dengan penurunan fungsi kognitif mulai dipikirkan karena pada berbagai penelitian longitudinal mengenai defisiensi besi di masa awal menunjukkan bahwa anak dengan anemia pada masa bayi cenderung memiliki fungsi kognitif, prestasi sekolah dan dan gangguan perilaku lebih buruk dibandingkan dengan anak yang tidak anemia. ${ }^{10}$

Terapi besi memberikan respon puncak dari retikulosit pada hari ke 5-7. Kemudian diikuti peningkatan $\mathrm{Hb}$ 1-2 g/minggu sampai kadar $\mathrm{Hb}$ mencapai normal dalam 4-6 minggu sejak terapi dimulai. Terapi besi harus diteruskan selama 2-3 bulan untuk mengisi cadangan besi, rekomendasi dosis besi 3-6 mg besi elemental/kgBB/hari dibagi 2 atau 3 dosis. ${ }^{8,11,12}$

Pada penelitian dinilai dampak anemia defisiensi besi terhadap fungsi kognitif serta membandingkan respon pemberian ferro sulfat satu kali dan tiga kali sehari dengan dosis total yang sama pada anak sekolah dasar yang menderita anemia defisiensi besi.

\section{Metode}

Penelitian dilakukan pada bulan November - Desember 2006 di Kecamatan Bilah Hulu Kabupaten Rantau Prapat. Subjek penelitian adalah anak sekolah dasar negeri yang berada di lokasi penelitian, darah kapiler diambil dari ujung jari $0,5 \mathrm{ml}$. Bila didapati hasil pemeriksaan sesuai dengan kriteria inklusi maka dimasukkan dalam sampel penelitian. Kriteria inklusi yaitu anak sekolah dasar negeri berusia 9-12 tahun yang menderita anemia defisiensi besi, mengikuti penelitian sampai selesai dan persetujuan tertulis dari orang tua. Kriteria eksklusi adalah anak menderita anemia berat, infeksi berat dan gizi buruk.

Penentuan diagnosis anemia dengan menggunakan kriteria WHO, yaitu kadar Hb untuk anak usia 6-14 tahun, kurang dari $12 \mathrm{~g} / \mathrm{dl}$. Didiagnosis anemia defisiensi besi apabila didapati $\mathrm{Hb}<12 \mathrm{~g} / \mathrm{dl}$, MCV $<70 \mathrm{fl}$, RDW $>16 \%$, indeks Mentzer $>13$ dan indeks RDW $>220$. Setelah dilakukan randomisasi, anak dikelompokkan ke dalam satu dari dua kelompok perlakuan yaitu ferro-sulfat satu kali sehari dan tiga kali sehari. Preparat besi diberikan setiap hari dalam bentuk kapsul ferro sulfat dengan dosis $5 \mathrm{mg}$ besi elemental per kilogram berat badan. Kapsul yang diberikan mempunyai bentuk dan rasa yang sama.

Darah kapiler 0,5 $\mathrm{ml}$ diambil sebelum dan setelah 30 hari terapi besi, kemudian dilakukan pemeriksaan hemoglobin, hematokrit, eritrosit, mean corpuscular volume (MCV), mean corpuscular hemoglobin (MCH), mean corpuscular hemoglobin concentration (MCHC), red cell distribution width (RDW). Pemeriksaan diukur dengan fotometer (ABX Mikros-60, France). Subjek ditimbang dan dinilai berat badan dengan menggunakan timbangan merk MIC (sensitif sampai $0,5 \mathrm{~kg}$ ) dan tinggi badan diukur dengan pengukur tinggi merk MIC (sensitif sampai $0,5 \mathrm{~cm}$ ). Fungsi kognitif dinilai dengan melakukan uji Weschler Intelligence Scale for Children yang dilakukan oleh tim psikolog dari FK USU. 
Data diolah dengan SPSS for windows 13 (SPSS Inc, Chicago). Analisis data untuk mengetahui rerata hasil laboratorium pada kedua kelompok sebelum dan sesudah terapi dengan uji $t$ independent atau Mann Withney test, dan untuk mengetahui perbedaan rerata sebelum dan sesudah terapi dengan uji t berpasangan atau Wilcoxon signed ranks test. Analisa hasil uji Weschler Intelligence Scale for Children dilakukan dengan uji korelasi Spearman rank dan uji chi square. Uji bermakna bila $p<0,05$. Penelitian telah mendapat persetujuan dari Komite Etik Penelitian Fakultas Kedokteran Universitas Sumatera Utara.

\section{Hasil}

Diantara 300 anak sekolah dasar yang dilakukan skrining didapati 156 orang (52\%) menderita anemia defisiensi besi, namun 50 orang anak tidak diikutsertakan karena 30 orang tua tidak bersedia menandatangani persetujuan penelitian dan 20 anak tidak bersedia diambil darah. Dari 106 orang yang ikut serta dalam penelitian, dilakukan randomisasi dan dibagi menjadi dua kelompok, 53 anak untuk kelompok kontrol mendapat besi tiga kali sehari dan sisanya 53 anak dimasukkan ke dalam kelompok perlakuan yang mendapat besi satu kali sehari dengan dosis yang sama. Setelah pemberian terapi besi selama 30 hari, hanya 97 orang yang mengikuti penelitian sampai akhir (47 orang dari kelompok kontrol dan 50 orang dari kelompok perlakuan).
Tidak didapati perbedaan bermakna dari jenis kelamin, rerata umur, berat badan, hemoglobin, dan parameter hematologi lainnya pada kedua kelompok saat permulaan penelitian (Tabel 1). Kadar hemoglobin, hematokrit, eritrosit, $\mathrm{MCH}, \mathrm{MCHC}$, RDW, dan indeks RDW meningkat bermakna pada kelompok besi tiga kali sehari, sedangkan hemoglobin, $\mathrm{MCH}, \mathrm{MCHC}$, dan RDW meningkat bermakna pada kelompok besi satu kali sehari setelah 30 hari terapi (Tabel 2).

Setelah 30 hari, rerata kadar hemoglobin di antara kedua kelompok yang diberikan besi tiga kali sehari dan satu kali sehari tidak berbeda bermakna (Tabel 3).

Selama periode penelitian terdapat 50 anak yang mengikuti uji Weschler. Subjek terdiri dari 28 (56\%) anak laki-laki dan 22 (44\%) anak perempuan. Dari Hasil uji Weschler Full IQ 83,80 (SD=13,14) dengan rerata Performance IQ dan Verbal IQ masing-masing $81,08(S D=14,58)$ dan 88,10 $(S D=14,20)$. Didapati hasil yang rendah pada skor aritmatika, yaitu 7 $(\mathrm{SD}=3,23)$. Persentase untuk masing-masing aspek dan tingkat Full IQ tertera pada Tabel 4 dan 5.

Hubungan antara tingkat anemia dengan Full IQ dianalisis dengan analisa korelasi dengan menggunakan Spearman Rank. Analisis ini menghasilkan nilai koefisien korelasi ( $\mathrm{r}$ ) sebesar 0,025 dengan $p=0,864$. Dengan demikian tidak didapati hubungan yang bermakna antara tingkat anemia dan Full IQ. Dengan menggunakan analisa chi square didapati bahwa tidak ada hubungan bermakna tingkat anemia dengan tingkat kecerdasan (Tabel 6)

Tabel 1. Karakteristik sampel

\begin{tabular}{lllc}
\hline \multicolumn{1}{c}{ Karakteristik } & Besi tiga kali sehari & \multicolumn{1}{c}{ Besi satu kali sehari } & $p$ \\
\hline Umur, bulan, rerata (SD) & $121,96(15,62)$ & $121,18(17,88)$ & 0,815 \\
Jenis Kelamin & & & \\
$\quad$ Laki-laki, n (\%) & $28(52,8)$ & $24(4,53)$ & 0,23 \\
$\quad$ Perempuan, n (\%) & $25(47,2)$ & $29(54,7)$ & 0,42 \\
Berat badan, kg, rerata (SD) & $26,88(6,52)$ & $27.89(6,11)$ & 0,90 \\
Hemoglobin (g/dl) & $10,09(1,32)$ & $10,31(1,22)$ & 0,79 \\
Hematokrit (\%) & $31,39(4,68)$ & $32,25(5,05)$ & 0,22 \\
Eritrosit (juta/mm3) & $4,28(0,66)$ & $5,01(3,90)$ & 0,19 \\
MCV (f) & $72,58(6,70)$ & $72,66(2,77)$ & 0,26 \\
MCH (pg) & $23,85(3,10)$ & $23,40(2,59)$ & 0,33 \\
MCHC (g/dl) & $32,43(3,68)$ & $31,93(3,12)$ & 0,39 \\
RDW (\%) & $15,65(1,24)$ & $15,81(2,11)$ & 0,21 \\
Indeks Mentzer & $17,71(4,32)$ & $16,50(3,02)$ & 0,35 \\
Indeks RDW & $278,72(77,76)$ & $261,11(64,5)$ & \\
\hline
\end{tabular}


Tabel 2. Perbedaan rerata parameter hematologi sebelum dan sesudah terapi

\begin{tabular}{|c|c|c|c|c|c|c|}
\hline \multirow{3}{*}{ Parameter hematologi } & \multicolumn{2}{|c|}{$\begin{array}{l}\text { Besi tiga kali sehari } \\
(\mathrm{n}=47)\end{array}$} & \multirow[b]{3}{*}{$P$} & \multicolumn{3}{|c|}{$\begin{array}{l}\text { Besi satu kali sehari } \\
\qquad(\mathrm{n}=50)\end{array}$} \\
\hline & $\mathrm{H} 0$ & $\mathrm{H} 30$ & & $\mathrm{H} 0$ & $\mathrm{H} 30$ & \\
\hline & Rerata (SD) & Rerata (SD) & & Rerata (SD) & Rerata (SD) & $p$ \\
\hline Hemoglobin $(\mathrm{g} / \mathrm{dl})$ & $10,01(1,33)$ & $12,34(1,35)$ & $0,00^{*}$ & $10,30(1,22)$ & $15,12(7,10)$ & $0,00^{*}$ \\
\hline Hematokrit (\%) & $31,20 \quad(4,69)$ & $33,06(3,71)$ & $0,01^{*}$ & $32,16(5,06)$ & $33,35(2,93)$ & 0,15 \\
\hline Eritrosit (juta/mm³) & $4,26 \quad(0,65)$ & $4,50 \quad(0,49)$ & $0,03^{*}$ & $5,01 \quad(3,80)$ & $4,59(0,40)$ & 0,9 \\
\hline $\operatorname{MCV}(\mathrm{fl})$ & $72,53 \quad(6,77)$ & $73,41 \quad(3,26)$ & 0,46 & $72,66(2,77)$ & $73,38(4,43)$ & 0,52 \\
\hline $\mathrm{MCH}(\mathrm{pg})$ & $23,87 \quad(3,3)$ & $27,25(2,55)$ & $0,00^{*}$ & $23,40 \quad(2,59)$ & $26,98(1,63)$ & $0,00^{*}$ \\
\hline MCHC (g/dl) & $32,47(3,70)$ & $37,40(2,42)$ & $0,00^{*}$ & $31,93(3,12)$ & $36,98(1,50)$ & $0,00^{*}$ \\
\hline RDW (\%) & $15,66(1,25)$ & $15,01(0,84)$ & $0,00^{*}$ & $15,81(2,11)$ & $14,90(1,20)$ & $0,00^{*}$ \\
\hline Indeks Mentzer & $17,79(4,3)$ & $16,49(2,25)$ & 0,10 & $16,50(3,02)$ & $16,12(1,98)$ & 0,99 \\
\hline Indeks RDW & $280,08(77,6)$ & $248,33(42,1)$ & $0,00^{*}$ & $261,11(64,05)$ & $240,51(39,44)$ & 0,07 \\
\hline
\end{tabular}

${ }^{*} p<0,05$

Tabel 3. Perbedaan rerata parameter hematologi sesudah terapi pada kedua kelompok

\begin{tabular}{lcccccc}
\hline \multirow{2}{*}{ Parameter hematologi } & $\begin{array}{c}\text { Besi tiga kali } \\
\text { sehari }(\mathrm{n}=47)\end{array}$ & $\begin{array}{c}\text { Besi satu kali } \\
\text { sehari }(\mathrm{n}=50)\end{array}$ & \multicolumn{3}{c}{ Batas kepercayaan $95 \%$} \\
\cline { 2 - 7 } & Rerata (SD) & Rerata (SD) & Beda rerata & Terendah & Tertinggi & $p$ \\
\hline Hemoglobin(g/dl) & $12,34(1,35)$ & $15,12(7,10)$ & $-2,77$ & $-4,86$ & $-0,68$ & 0,29 \\
Hematokrit (\%) & $33,06(3,71)$ & $33,35(2,93)$ & $-0,25$ & $-1,59$ & 1,08 & 0,70 \\
Eritrosit(juta/mm $)$ & $4,50(0,49)$ & $4,59(0,40)$ & $-0,08$ & $-0,26$ & 0,09 & 0,35 \\
MCV (fl) & $73,41(3,26)$ & $73,38(4,43)$ & 0,02 & $-1,54$ & 1,59 & 0,61 \\
MCH (pg) & $27,25(2,55)$ & $26,98(1,63)$ & 0,26 & $-0,58$ & 1,11 & 0,96 \\
MCHC (g/dl) & $37,40(2,42)$ & $36,98(1,50)$ & 0,40 & $-0,39$ & 1,20 & 0,95 \\
RDW (\%) & $15,01(0,84)$ & $14,90(1,20)$ & 0,10 & $-0,31$ & 0,52 & 0,12 \\
Indeks Mentzer & $16,49(2,25)$ & $16,12(1,98)$ & 0,35 & $-0,49$ & 1,20 & 0,35 \\
Indeks RDW & $248,33(42,1)$ & $240,51(39,44)$ & 7,29 & $-9,09$ & 23,68 & 0,19 \\
\hline
\end{tabular}

$$
{ }^{*} p<0,05
$$

Tabel 4. Hasil uji Weschler

\begin{tabular}{ll}
\hline & Mean (SD) \\
\hline Information & $9,27(2,79)$ \\
Comprehension & $6,35(2,85)$ \\
Arithmetic & $7,00(3,23)$ \\
Similarities & $9,51(3,82)$ \\
Digit Span & $8,24(2,26)$ \\
Picture Completion & $7,35(2,96)$ \\
Picture Arrangement & $6,55(3,15)$ \\
Block Design & $8,37(3,13)$ \\
Object Assembly & $5,41(2,88)$ \\
Coding & $9,49(3,20)$ \\
Full IQ & $83,80(\mathrm{SD}=13,14)$ \\
Performance IQ & $81,08(\mathrm{SD}=14,58$ \\
Verbal IQ & $88,10(\mathrm{SD}=14,20)$ \\
\hline
\end{tabular}

Tabel 5. Hasil uji Weschler ( Tingkat Full IQ)

\begin{tabular}{lc}
\hline Full IQ Gradation & $\mathrm{n}(\%)$ \\
\hline Average & $18(36)$ \\
Dull nornal & $14(28)$ \\
Borderline & $12(24)$ \\
Mental defective & $5(10)$ \\
\hline
\end{tabular}

Tabel 6. Hubungan tingkat anemia dengan tingkat kecerdasan

\begin{tabular}{lc}
\hline & $p$ \\
\hline Verbal IQ & 0,980 \\
Performance IQ & 0,636 \\
Full IQ & 0,119 \\
Full IQ Gradation & 0,589 \\
\hline
\end{tabular}




\section{Diskusi}

Baku emas untuk mendiagnosis anemia defisiensi besi (ADB) adalah pemeriksaan aspirasi sumsum tulang dengan pengecatan Prussian blue, secara rutin tidak dilakukan karena invasif. Pemeriksaan darah tepi tidak cukup sensitif dibanding pemeriksaan kimia darah, namun lebih mudah dan murah dilakukan. ${ }^{13}$ Pemeriksaan kadar hemoglobin dan hematokrit bukan merupakan tes diagnostik pilihan karena kadar $\mathrm{Hb}$ atau Ht tidak sensitif terhadap ADB. Tahap awal terjadinya ADB tidak dapat terdeteksi dengan pemeriksaan kadar $\mathrm{Hb}$ dan $\mathrm{Ht}$, namun diperlukan untuk menentukan keparahan derajat anemia. ${ }^{14}$ Pemeriksaan kadar $\mathrm{Hb}$ dan Ht juga tidak spesifik karena banyak penyebab anemia selain defisiensi besi. ${ }^{15}$ Pada penelitian kami menggunakan pemeriksaan yang sederhana dalam menegakkan diagnosis anemia defisiensi besi yaitu $\mathrm{Hb}$, $\mathrm{Ht}, \mathrm{MCV}$, RDW, Mentzer indeks, dan RDW indeks, relatif murah dan dapat dilaksanakan di daerah dengan sarana yang terbatas.

Pemeriksaan darah tepi yang mengarah terhadap kecurigaan ADB adalah mikrositik hipokromik, sedangkan pemeriksaaan kadar feritin serum merupakan uji diagnostik yang paling baik untuk ADB dengan sensitivitas dan spesifisitas paling baik. Kadar feritin serum pada anak $\mathrm{ADB}<12 \mathrm{ug} / \mathrm{L}$, namun kurang lazim dipakai sebagai pemeriksaan skrining karena relatif mahal. ${ }^{13,14}$ Nilai RDW meningkat dengan MCV menurun mengarah ke diagnosis defisiensi besi. ${ }^{15}$ Salah satu cara untuk membedakan ADB dengan talasemia minor, dengan pemeriksaan indeks Mentzer (MCV/ $\mathrm{RBC}$ ), apabila indeks Mentzer $>13$ merupakan ADB dan bila $<13$ menunjukkan talasemia minor. ${ }^{11}$

Lozoff ${ }^{17}$ melakukan penelitian di Kostarika dan mendapatkan bahwa anak dengan anemia memiliki skor perkembangan kognitif dan motorik lebih rendah dibandingkan dengan anak yang tidak anemia. Selain itu ditemukan juga bahwa anak yang tidak anemia namun memiliki defisiensi besi juga memiliki skor yang lebih rendah. Halterman ${ }^{14}$ di Amerika Serikat, mendapatkan bahwa anak usia sekolah yang menderita anemia defisiensi besi mempunyai nilai matematika yang lebih rendah dibandingkan anak dengan status besi normal dan nilai the block design test juga lebih rendah.

Penelitian Lozoff ${ }^{18}$ merupakan kelanjutan dari penelitiannya tahun 1991 mendapatkan bahwa anak dengan defisiensi besi cenderung lebih merasa cemas atau depresi, memiliki gangguan perhatian serta masalah sosial. Anak dengan defisiensi besi juga lebih sering mengulang kelas dan mendapatkan perlakuan khusus. Anak dengan anemia defisiensi besi kronis atau berat pada masa bayi memiliki gangguan tumbuh kembang dan gangguan perilaku setelah lebih dari 10 tahun pasca terapi.

Stoltzfus ${ }^{19}$ dalam penelitiannya di Zanzibar melaporkan bahwa suplementasi zat besi meningkatkan perkembangan motorik dan bahasa pada anak usia prasekolah namun secara klinis tidak bermakna Anak yang pernah mengalami defisiensi besi menunjukkan skor motorik, IQ verbal, dan IQ keseluruhan yang rendah pada umur 11-14 tahun. ${ }^{16}$ Defisiensi besi pada anak usia sekolah menyebabkan gangguan pemusatan perhatian dan gangguan kognitif terutama dalam bidang matematika. ${ }^{20}$ Pada penelitian kami didapati kebanyakan anak ADB memiliki kemampuan berhitung yang rendah serta tingkat Full IQ tidak ada yang melebihi rata-rata (average). Tidak didapati hubungan yang bermakna antara tingkat anemia dengan masing-masing aspek kognitif. Hal ini dapat dipengaruhi oleh homogenitas sampel, seluruh sampel merupakan pasien anemia dengan tingkat anemia ringan atau sangat ringan.

Pada berbagai penelitian longitudinal mengenai defisiensi besi di masa awal menunjukkan bahwa anak dengan anemia pada masa bayi cenderung memiliki fungsi kognitif, prestasi sekolah, dan gangguan perilaku lebih buruk dibandingkan dengan anak yang tidak anemia. Bila anak menderita anemia defisiensi besi saat berusia $<2$ tahun, walaupun sudah diberikan suplemen besi anak tersebut tidak bisa mengejar perkembangan anak yang tidak menderita anemia. ${ }^{10}$ Kami tidak dapat memastikan apakah anemia defisiensi besi telah terjadi sejak usia dini.

Schultink $\mathrm{dkk}^{22}$ mendapatkan dampak yang sama terhadap hemoglobin antara pemberian besi setiap hari dengan pemberian dua kali seminggu terhadap anak prasekolah dengan status besi rendah. Kruske SG $\mathrm{dkk}^{23}$ mendapatkan pemberian suplemen besi dua kali seminggu disertai pengawasan secara bermakna lebih baik daripada pemberian suplemen besi setiap hari tetapi tanpa disertai pengawasan, khususnya dalam meningkatkan kadar Hb. Namun Desai dkk ${ }^{24}$ menemukan hasil yang berbeda, pemberian suplemen besi tiap hari disertai pengawasan meningkatkan kadar $\mathrm{Hb}$ secara lebih baik dan bermakna daripada pemberian dua kali seminggu disertai pengawasan. Dalam studi kami kenaikan kadar $\mathrm{Hb}$ secara signifikan telah terde- 
teksi 6 hingga 12 minggu setelah intervensi. Pemberian ferro-sulfat satu kali sehari memberikan hasil yang tidak berbeda dibandingkan tiga kali sehari dengan dosis total yang sama dalam meningkatkan hemoglobin pada anak usia sekolah dasar.

Sebagai kesimpulan, pada anak usia sekolah dasar yang mengalami anemia defisiensi besi didapatkan Full IQ yang tidak melebihi rata-rata, serta gangguan pemusatan perhatian dan gangguan kognitif terutama dalam bidang matematika. Pemberian ferro-sulfat satu kali sehari memberikan hasil yang tidak berbeda dibandingkan tiga kali sehari dengan dosis total yang sama dalam meningkatkan hemoglobin pada anak usia 9-12 tahun.

\section{Daftar Pustaka}

1. Fomon SJ. Iron. Dalam: Fomon SJ, penyunting. Infant nutrition. Edisi ke 2. Philadelphia: WB Saunders, 1974. h.299-317.

2. Raspati H, Reniarti L, Susanah S. Anemia defisiensi besi. Dalam: Permono B, Sutaryo, Ugrasena IDG, Windiastuti E, Abdulsalam M, penyunting. Buku ajar hematology onkologi anak. Badan penerbit IDAI; 2005. h. 30-43.

3. Lukens JN. Iron metabolism and iron deficiency. Dalam: Miller DR, Bachner RL, Miller LP, penyunting. Blood diseases of infancy and childhood. Edisi ke 7. Toronto: Mosby; 1995. h. 193-219.

4. Weatheral DJ, Kwiatkowski D. Hematologic disorders of children in developing countries. Pediatr Clin N Am 2002;49:1149-64.

5. Dirjen Kesmas Depkes RI. Situasi gizi terkini dan penanggulangan masalah gizi di Indonesia. Depkes RI, Juli 2000 .

6. Soedjatmiko, Sekartini R. Anemia pada anak sekolah di 11 propinsi di Indonesia. IDAI, 2003.

7. Schwartz E. Iron deficiency anemia. Dalam: Behrman RE, Kliegman RM, Jenson HB, penyunting. Nelson textbook of pediatrics. Edisi ke 17. Philadelphia: WB Saunders; 2004. h. 1614-16.

8. Will AM. Iron metabolism, sideroblastic anemia and iron overload. Dalam: Lilleyman JS, Hann IM, Blanchette VS, penyunting. Pediatric hematology. Edisi ke 2. New York: Churchill Livingstone; 2000. h. 105-12.

9. Oski FA. Iron deficiency in infancy and childhood. N Engl J Med 1993;329:190-3.

10. McGregor SG, Ani C. A Review of studies on the effect of iron deficiency on cognitive development in children.
J Nutr 2001;131:649S-68S.

11. Sandoval C, Jayabose S, Eden AN. Trends in diagnosis and management of iron deficiency during infancy and early childhood. Hematol Oncol Clin N Am 2004;18:h.1423-38.

12. Zlotkin S, Arthur P, Antwi KY, Yeung G. Randomized controlled trial of single versus 3-times daily ferrous sulfate drops for treatment of anemia. Pediatrics 2001;108:613.

13. Wu AC, Lesperance L, Bernstein H. Screening for iron deficiency. Pediatrics in Review 2000;23:171-7.

14. Halterman JS, Kaczorowski JM, Aligne CA, Auinger P, Szilagy,PG. Iron deficiency and cognitive achievement among school aged children and adolescents in the United States. Pediatrics 2001;107:1381-6.

15. Andrews NC. Disorders of iron metabolism. N Engl J Med 1999;341:1986-95.

16. Irwin JJ, Kirchner JT. Anemia in children. Am Fam Physician 2001;64:1379-86.

17. Lozoff B, Jimenez E, Wolf AW. Long-term developmental outcome of infants with iron deficiency. N Engl J Med 1991;325:687-94

18. Lozoff B, Jimenez E, Hagen J, Mollen E, Wolf AW. Poorer behavioral and developmental outcome more than 10 years after treatment for iron deficiency in infancy. Pediatrics 2000;105:E51.

19. Stoltzfus RJ. Effects of iron supplementation and anthelmintic treatment on motor and language development of preschool children in Zanzibar: double blind, placebo controlled study. BMJ 2001;323:1-8.

20. Yager JY, Hartfield DS. Neurologic manifestations of iron deficiency in childhood. Pediatr Neurol 2002;27:8592.

21. Araneda M, Krishnan V, Hall K. Reactive and clonal thrombocytosis: proinflammatory and hematopoitic cytokines and acute phase proteins. South Med J 2001;94;417-20.

22. Schultink WS, Gross R, Gliwitzki, Karyadi D,Matulessi P. Effect of daily vs twice weekly iron supplementation in Indonesia preschool children with low iron status. Am J Clin Nutr 1995;61:111-15.

23. Kruske SG, Ruben AR, Brewster DR. An iron treatment trial in an aboriginal community: improving non adherence. J Pediatr Child Health 1999;35:153-8.

24. Desai MR, Dhar R, Rosen DH, Kariuki SK, Shi YP, Kager PA. Daily iron supplementation is more efficacious than twice weekly iron supplementation for the treatment of childhood anemia in Western Kenya. J Nutrition 2004;134:1167-74. 